\title{
KURIKULUM 2013 DALAM PERSEPSI DAN INTERPRETASI GURU-GURU BAHASA INGGRIS SMA KOTA MAKASSAR
}

\author{
Djuwariah Ahmad dan Mardiana \\ Pendidikan Bahasa Inggris, Fakultas Tarbiyah dan Keguruan UIN Alauddin Makassar
}

\begin{abstract}
Abstrak
Makalah ini bertujuan mendeskripsikan secara analitik persepsi dan interpretasi guru-guru bahasa Inggris terhadap Kurikulum 2013 berdasarkan hasil penelitian pada 4 SMA target implementasi di Kota Makassar. Penelitian ini menggunakan metode deskriptif analitik dengan pendekatan fenomenologi dalam paradigma kualitatif yang melibatkan 11 guru bahasa Inggris di Kelas X. Hasil penelitian menunjukkan bahwa sejalan dengan pengetahuan dan sistem kepercayaan yang dibangun guru terhadap perubahan, persepsi mereka terhadap pembelajaran bahasa Inggris dalam Kurikulum 2013 berada pada dua kutub; positif (berdampak pada transformasi dari pandangan tradisional pembelajaran menuju dimensi pedagogik modern) dan negatif yang menganggap bahwa perubahan hanya pada tingkat konseptual dengan efek yang sama pada kurikulum sebelumnya. Interpretasi guru cenderung benar dan menyeluruh pada konsep-konsep umum Kurikulum 2013 namun parsial terhadap konsep-konsep aplikatif sesuai dengan tingkat pemahaman, pengetahuan prosedural dan kenyamanan yang diperoleh dari aplikasi yang ditawarkan oleh elemen kurikulum yang berubah.
\end{abstract}

Kata Kunci: persepsi, interpretasi, Kurikulum 2013

\begin{abstract}
This paper aims to analytically describe the perception and interpretation of English teachers on the 2013 Curriculum based on the research at the four senior secondary school targets of implementation in Makassar. An analytic descriptive method with a phenomenological approach in qualitative paradigm was used and involved 11 teachers of English in Grade $\mathrm{X}$.The results showedthatin linewiththe teacher's knowledgeandbelief systemto the change, their perceptionled to two main strands. The positive perception tends to lead them to transform from the traditional view of learning to the modern pedagogic dimension. The negative perception assumesthat the change happened onlyat the conceptual level and will have the same effectsas in thepreviouscurricula. Interpretationof teacherstends to be trueandthoroughon the general conceptsin the 2013 Curriculum but partial onthe applicative conceptsin accordancewith theirlevel of understanding, proceduralknowledgeandcomfort provided by the changing elements ofthe curriculum.
\end{abstract}

Keywords: perception, interpretation, 2013 Curriculum

\section{PENDAHULUAN}

Terdapat asumsi yang kuat bahwa kunci keberhasilan Kurikulum 2013 (selanjutnya ditulis K-13) terletak pada perubahan mindset guru. Guru dengan sendirinya menjadi fokus utama yang harus memiliki komitmen perubahan dalam pelaksanaan pembelajaran yang ujung-ujungnya berakhir di kelas. Dalam pembelajaran Bahasa Inggris, isu yang mewarnai pro-kontra implementasi $\mathrm{K}-13$ adalah pengurangan jam pelajaran wajib untuk Bahasa Inggris dari 4 jam per minggu menjadi 2 jam per minggu. Selain itu, guruguru Bahasa Inggris di jenjang pendidikan dasar (SD)yang terlanjur tersertifikasi pada mata pelajaran ini juga merasa kehilangan 
kesempatan memperoleh jam mengajar sebagai syarat mendapatkan tunjangan tersebut. Meskipun demikian, keputusan implementasi K-13 telah ditetapkan berdasarkan berbagai pertimbangan. Untuk menjamin implementasi berjalan sebagaimana harusnya, guru-guru yang dipersiapkan mengajar di kelas X diwajibkan mengikuti Bimtek Kurikulum 2013 meskipun konten Bimtek masih bersifat pemaparan umum atau memuat konsep-konsep umum pada K-13.

Perspesi dan interpretasi guru terhadap K-13 penting diketahui untuk mengukur kesesuaian antara kebijakan yang dikeluarkan oleh pemerintah dengan penerimaan dan pemahaman guru terhadap kebijakankebijakan tersebut. Perlu dipahami bahwa kebijakan pemerintah yang dituangkan dalam bentuk peraturan tertulis akan disikapi dan diinterpretasi berdasarkan pengetahuan, pengalaman, dan sistem kepercayaan yang dimiliki oleh guru sementara guru merupakan implementer utama muatan kebijakan tersebut.

Dipostulatkan bahwa pada setiap perubahan kurikulum pemerintah memiliki sejumlah agenda yang bertujuan meningkatkan mutu pendidikan, memperbaiki, dan meningkatkan bagianbagian tertentu dalam praktek pembelajaran di sekolah. Pada dasarnya, setiap implementasi kebijakan kurikulum yang diberlakukan oleh pemerintah sangat ditentukan oleh kemampuan guru mengimplementasi dengan benar. Implementasi tersebut sedikit banyaknya dipengaruhi oleh persespi dan interpretasi yang dimiliki oleh guru-guru.Persepsi dan interpretasi guru terhadap kurikulum berakar pada pengetahuan dan pengalaman guru itu sendiri (Lundeberg dan Levin, 2003;
Richardson, 2003; dan Basturkman, Loewen dan Ellis, 2004; Senior, 2006).

Selanjutnya, Elmore dan Sykes (1992) berpostulat bahwa ketika kurikulum diformulasi, dikembangkan, dan diimplementasikan di sistem persekolahan hingga ke dalam kelas, mekanisme pelaksanaan mempengaruhi praktek pembelajaran yang selanjutnya berpengaruh terhadap hasil belajar siswa. Sayangnya, menurut Elmore dan Sykes (1992), tidak ada jaminan bahwa guru akan mengimplementasikan kebijakan kurikulum sesuai harapan pemerintah. Markee (1997) juga menegaskan bahwa guru memiliki kecenderungan mengubah dan memodiflkasi kebijakan tersebut sesuai dengan kemampuan implementasinya karena adanya beberapa hambatan dalam praktek pembelajaran.

Dalam pembelajaran bahasa Inggris, kurikulum diartikan sebagai program studi khusus yang terkait dengan perencanaan, implementasi serta evaluasi yang selanjutnya dikontraskan dengan pengerrian silabus. Secara spesifik, kurikulum menyangkut semua kegiatan yang dilakukan siswa di sekolah dengan fokus pada konten pembelajaran, teknik pembelajaran, fasilitasi guru, mated, penilaian, dan alat bantu pembelajaran (Robertson, 1971:566; Dubin dan Olshtain, 1986:3; Krahnke, 1987:2; Yalden, 1987; Nunan, 1988:14; Rodgers, 1989:26).

Evolusi kurikulum pembelajaran bahasa Inggris di Indonesia dari GTM berakhir dengan penekanan pada pengembangan nilainilai karakter di K-13. Paradigma baru ini terlihat pada rumusan Kompetansi Inti (KI) yang memuat Kompetensi Spiritual pada KI.1, Kompetensi Sosial pada KI.2, Kompetensi Kognitif pada KI.3, dan Kompetensi Psikomotor pada KI.4. Kompetensi Spiritual dan Sosial tidak 
diajarkan secara langsung tetapi menjadi dampak pengiring pada pencapaian kompetensi kognitif dan psikomotor. Pembentukan karakter dan penanaman nilainilai spiritual dan sosial dilakukan melalui pemberian contoh atau keteladanan. Penilaiannya dilakukan dengan pengamatan proses yang melibatkan jenis penilaian otentik dengan pendekatan pembelajaran saintifik.

\section{METODE}

Penelitian ini menggunakan metode deskriptif analitik dengan ancangan fenomenologis dalam paradigma kualitatif. Dengan melibatkan 11 guru bahasa Inggris sebagai responden penelitian pada empat SMA target implementasi K-13 di Kota Makassar, dilakukan teknik wawancara mendalam dan kuesioner untuk menjaring persepsi dan interpretasi mereka terhadap K13 sebagai obyek penelitian. Wawancara mendalam dan kuesioner menggunakan bahasa Inggris sebagai bahasa pengantar dan peneliti bertindak sebagai pewawancara, pengumpul, dan pengolah data. Pengambilan data dilakukan selama kurang lebih delapan bulan.Kroscek data untuk memastikan validitas data yang diberikan oleh responden dilakukan melalui telepon dan tatap muka dengan memperhatikan prinsip credibility, transferability, dependability, dan conformability. Data dianalisis dengan menggunakan analisis kualitatif (open coding, axial coding, dan selective coding) dengan memanfaatkan diagram alur yang dikemukakan oleh Miles dan Huberman (1994).

\section{HASIL DAN PEMBAHASAN}

\section{Persepsi Guru}

Studi tentang persepsi dan kepercayaan (belief) dalam pembelajaran bahasa asing telah dilakukan oleh berbagai peneliti karena peran dan dampaknya terhadap guru dan siswa. Persepsi dan keyakinan juga mempengaruhi cara guru melihat kebijakan dan dapat bertindak tidak sejalan dengan kebijakan yang dimaksudkan karena adanya proses penerimaan dan pemahaman secara individual (Bekalo dan Welford, 2000; Connelly dan Lantz, 1991; Elmore dan Sykes, 1992; Karavas-Doukas, 1995; dan Markee, 1997). O'Sullivan (2002) bahkan menggambarkan kebijakan kurikulum sebagai 'kotak hitam' yang berisi tantangan, kompleksitas, dan potensi hubungan yang tidak kongruen dengan praktiknya.

Secara garis besar, persepsi guru terhadap K-13 dalam kaitannya dengan pembelajaran bahasa Inggris dalam penelitian ini mengacu pada kepraktisan K-13, perubahan positif pada perilaku siswa dalam kegiatan pembelajaran, materi ajar yang adaptif dan inklusif, kesulitan penerapan pendekatan saintifik, dan kemudahan dalam penilaian otentik. Kepraktisan K-13 disebabkan oleh kemudahan menerapkan penilaian otentik terutama pada penilaian ranah afektif, ketersediaan materi pembelajaran, penyusunan RPP, dan tidak diharuskannya guru menyusun silabus dan kurikulum.Perubahan positif perilaku siswa terlihat dengan siswa lebih aktif dalam kegiatan pembelajaran, khususnya yang berbasis proyek.Materi ajar yang adaptif dan inklusif mengedepankan kreativitas guru dalam memanfaatkan kekayaan sumber belajar era teknologi informasi meskipun buku teks wajib belum tersedia dan mengurangi kesempatan guru melakukan transaksi bisnis dengan penerbitan. Pendekatan saintifik dirasakan sulit karena 
belum spesifiknya petunjuk penerapannya seperti yang dilakukan oleh pemerintah dalam penyediaan alat-alat penilaian otentik terutama pada ranah afektif.

Oleh karena itu, peneliti mencoba membangun sub-gagasan bahwa persepsi positif yang dapat mengurangi skeptisisme terhadap kebijakan baru dalam pergeseran kurikulum dapat ditingkatkan hanya jika: (1) pergeseran atau perubahan kurikulum sesuai dengan tingkat pemahaman guru terhadap kebijakan tersebut dan dalam implementasinya memang terbukti bermanfaat; (2) guru percaya bahwa beban kerja mereka menurun dan (3) ada pedoman prosedural yang jelas dan dapat diimplementasikan mengikuti kebijakan tersebut. Artinya, jika ada bagian dari kurikulum yang masih harus dibuat oleh guru, maka mereka akan menganggapnya sebagai sesuatu yang menyulitkan dan akan memilih untuk melaksanakan bagain tertentu saja dari kurikulum. Dengan kata lain, setiap hambatan yang ditemukan dalam proses implementasi kurikulum akan cenderung diabaikan oleh guru.

\section{Interpretasi Guru}

Interpretasi guru terhadap pembelajaran Bahasa Inggris dalam K-13 dipetakan dalam empat tema, yaitu perbedaan SK dan KI, perumusan indikator dan tata urutan analisis KD dalam RPP, 'Fakta' dalam materi naratif, pendekatan saintifik, dan penilaian otentik. Terhadap SK dan KI, guru menginterpretasi bahwa KI lebih sederhana dan SK lebih rumit, KI sama untuk semua mata pelajaran dan SK berbeda, KI tidak diajarkan dan SK diajarkan, tiga ranah kompetensi pada KI terpetakan dengan jelas dan pada SK didominasi ranah kognitif, outcome KI bersifat holistik dan SK parsial, KI menuntut penerapan pendekatan saintifik dan penilaian otentik (penilaian berbasis kelas), sementara SK tidak. Interpretasi ini sesuai dengan penjelasan berbagai materi K-13 dan terlihat bahwa pemahaman guru-gurudinyatakan kongruen.

Terhadap pengembangan indikator dan pengurutan KI dalam RPP, guru menginterpretasi bahwa indikator pencapaian kompetensi dikembangkan dari KD dan materi ajar.Materi harus mendukung indikator dan indikator dapat dicapai melalui penggunaan bahasa yang telah dipelajari oleh siswa.Pengembangan indikator dilakukan dengan memberikan siswa bacaan yang berisi kompetensi spiritual kemudian menanyai siswa tentang pelajaran yang mereka peroleh dari teks bacaan tersebut. Pengembangan indikator pencapaian kompetensi harus bersesuaian dengan silabus, tingkat kesulitan materi ajar, dan kompetensi siswa.Urutan penyusunan indikator dari mudah ke sulk dan memperhatikan langkah-langkah dalam pendekatan saintifik.

Pemerintah menjelaskan bahwa pengembangan indikator pencapaian kompetensi dilakukan dengan menggunakan kata kerja operasional yang terukur dan teramati. Pengembangan indikator dimulai dengan menganalisis KD pada KI.3 beserta semua aspeknya lalu diteruskan dengan analisis dan pengembangan indikator $\mathrm{KD}$ pada KI.4 yang bersesuaian dengan KD pada KI.3 atau yang kongruen.Adapun KD pada KI.2 dan KI.l tidak perlu dikembangkan karena merupakan dampak pengiring dari

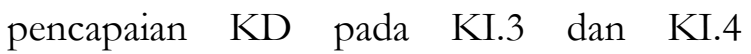
(Kementerian Pendidikan dan Kebudayaan, 2013).

$\begin{array}{lcr}\begin{array}{l}\text { Pemahaman } \\ \text { pengembangan }\end{array} & \begin{array}{c}\text { guru } \\ \text { indikator }\end{array} & \begin{array}{r}\text { terhadap } \\ \text { pencapaian }\end{array} \\ \text { kompetensi serta } & \text { pola urutan } & \text { analisis KI } \\ \text { dalam } \quad \text { RPP } & \text { masih } & \text { cenderung }\end{array}$


parsial.Pemahaman parsial terjadi karena ketidaksempurnaan pemahaman prosedural guru selama dalam Bimtek K-13.Selain itu, guru-guru mengakui bahwa dalam penyusunan RPP, mereka hanya mengikuti contoh yang ada dan mengadaptasinya sesuai pengetahuan mereka. Hal ini tentu saja akan menyebabkan lahirnya sikap apatis dalam penyelesaian tugas administratif guru dan akhirnya mereka akan kembali ke kebiasaan lama bahwa RPP disusun hanya untuk pengawas atau untuk kepentingan administratif semata.

Fakta sebagai obyek yang teramati dalam pembelajaran berbasis pendekatan saintifik merupakan suatu syarat dan dapat melahirkan ketaksaan dalam materi ajar Bahasa Inggris. Dinyatakan bahwa substansi materi pembelajaran harus berdasarkan fakta atau fenomena yang dapat dijelaskan dengan logika atau nalar dan tidak berasal dari kirakira, fantasi, legenda atau mitos.Masalahnya adalah banyak konten pembelajaran Bahasa Inggris berupa cerita narasi atau hayalan dan otomatis tidak logis.

Interpretasi guru terhadap pertanyaan tersebut bahwa materi-materi semacam itu masuk dalam kategori teks imajiner tanpa penjelasan lebih rinci yang dapat menguatkan argumennya untuk menjawab pertanyaan kuesioner. Sekelompok guru juga memiliki kecenderungan menilai bahwa materi ajar memang harus sesuai dengan pendekatan saintifik yang mengusung fakta sebagai dasar pengamatan tanpa penjelasan mengenai kehadiran materi-materi yang tidak berbasis fakta seperti cerita dongeng. Dalam pembelajaran bahasa, materi ajar berupa teks, kalimat, dan gambar yang kemudian dijadikan sebagai fakta atau fenomena yang dapat diamati oleh siswa. Adapun konsep cerita dongeng yang bukan fakta hanya perlu penjelasan kepada siswa sehingga pengamatan mereka lakukan pada fakta-fakta di balik cerita itu.Buku ajar yang dijanjikan belum diterima hingga saat penelitian dilakukan sehingga sebagian guru-guru mencoba mengalihkan tujuan pertanyaan dengan respon tersebut.

Komentar interpretatif guru pada kasus ini menunjukkan bahwa sebagian besar guru belum memiliki pemahaman yang terperinci dalam menyampaikan makna kriteria ilmiah dalam konten tertentu dari materi pembelajaran Bahasa Inggris.Hal ini menyiratkan bahwa guru masih memerlukan penjelasan yang lebih rinci mengenai hal tersebut untuk menghindari efek dari pemahaman parsial dalam pengetahuan prosedural.

Salah satu ciri yang menonjol dalam K13 adalah penggunaan pendekatan saintifik dalam pembelajaran untuk semua mata pelajaran seperti yang tertuang dalam Permendikbud Nomor 65 Tahun 2013 tentang Standar Proses Pendidikan Dasar dan Menengah. Interpretasi guru terhadap pendekatan saintifik antara lain bahwa guru mencoba menghubungkan antara pendekatan saintifik dengan pembelajaran bahasa Inggris secara umum. Hal ini digambarkan dengan ungkapan bahwa pendekatan saintifik termasuk dalam dimensi pedagogik modern yang mengedepankan cara-cara ilmiah untuk memperoleh ilmu pengetahuan, termasuk bahasa. Guru memberikan gambaran bahwa pendekatan saintifik merupakan lima tahapan pembelajaran yang meliputi kegiatan siswa dalam mengamati hingga mengomunikasikan dalam upaya penyelesaian masalah, pengembangan kreativitas, dan pencapaian tujuan pembelajaran.Ada juga guru yang hanya mendefinisikan pendekatan saintifik secara umum tanpa mencoba membuat hubungan dengan pembelajaran Bahasa Inggris. 
Khusus untuk masalah ini, peneliti mencoba menggunakan pendekatan yang berbeda dalam melihat respon guru. Peneliti menghubungkan cara mereka menafsirkan pendekatan saintifik dalam praktek pembelajaran bahasa Inggris berdasarkan latar belakang dan keterlibatan mereka dalam pelatihan K-13 yang mungkin menambah pengetahuan mereka dalam pendekatan saintifik. Ternyata, pelatihan K-13 dalam bentuk Bimtek atau sosialisasi tidak menjamin terjadinya perubahan pengetahuan guru secara signitikan dalam memahami pendekatan saintifik.

Pertama, guru-guru yang menghubungkan pendekatan saintifik dengan pengajaran bahasa Inggris memiliki tanggapan yang lebih terurai dan rinci. Tanggapan mereka menunjukkan tingkat pemahaman yang baik pada pendekatan saintifik dan menganggap bahwa pendekatan ini menawarkan model kompetensi berbahasa. Mereka percaya bahwa lima langkah dari proses ilmiah ini sejalan dengan cara siswa belajar bahasa dan akan menunjang keberhasilan pembelajaran bahasa jika diterapkan dengan benar. Kelompok ini terdiri dari guru-guru yang mengikuti pelatihan K-13 dengan mode yang berbeda.

Kedua, guru-guru yang mengomentari kasus ini dari perspektif siswa juga datang dari latar belakang beragam serta mengikuti pelatihan K-13. Komentar mereka masih sangat generik tapi dalam beberapa hal cenderung prosedural dengan menyatakan bahwa kelima langkah dalam pendekatan saintifik mampu melatih siswa menemukan masalah, tertarik menyelidiki, lebih mudah mengikuti pelajaran, mencapai tujuan pembelajaran, dan meningkatkan kreativitas mereka. Dari titik ini dapat disimpulkan bahwa guru, tidak peduli berapa lama dan berapa kali mereka telah mengikuti pelatihan K-13 akan menginterpretasi pendekatan saintifik dengan cara yang sama dan benar.

Ketiga, guru-guru yang tidak mencoba membuat hubungan antara pendekatan saintifik dan praktek pembelajaran bahasa Inggris juga telah mengikuti pelatihan K-13 bahkan lebih dari tiga kali. Mereka menjawab pertanyaan dengan menulis pengertian umum pendekatan saintifik tanpa menghubungkannya dengan pembelajaran Bahasa Inggris. Artinya, mereka memahami pendekatan saintifik namun mereka tidak memperoleh tambahan pengetahuan yang membuat mereka seharusnya mampu memahami penerapan pendekatan saintifik dalam pembelajaran bahasa Inggris.

Selanjutnya, penilaian otentik bersesuaian dengan pendekatan saintifik yang dalam pelaksanaannya digunakan input, proses, outputyung meliputi aspek kompetensi sikap, pengetahuan, dan keterampilan dan mengacu pada SKL, KI, dan KD pada semua jenjang. Interpretasi guru-guru terbagi ke dalam dua kategori, yaitu jawaban yang mencoba menghubungkan antara konsep penilaian otentik dengan pembelajaran Bahasa Inggris dan jawaban yang hanya mengemukakan definisi penilaian otentik.Unsur K-13 yang ikut mewarnai inovasinya adalab penggunaan penilaian otentik.Konsep ini berlaku untuk semua mata pelajaran, termasuk pelajaran Bahasa Inggris. Penilaian otentik sejalan dengan pendekatan saintifik dengan target penilaian input, proses, dan output serta mencakup aspek kompetensi sikap, kognitif, dan psikomotorik yang mengacu pada hasil KI dan KD pada semua tingkatan.

Interpretasi guru pada penilaian otentik relatif serupa dalam menggambarkan pengertian penilaian secara umum. Meskipun demikian sangat minim yang mampu 
menjelaskannya terkait dengan penerapan penilaian otentik dalam praktekpembelajaran bahasa Inggris.Tren umum yang digambarkan bahwa penilaian otentik dipandang dari perspektif tiga kompetensi yang berbeda atau domain dari Taksonomi Bloom yang harus dinilai. Selain itu, mereka juga menggambarkan kebutuhan untuk kriteria khusus penilaian yang terkait dengan konstruksi pengetahuan, mengamati aktivitas, dan nilai-nilai yang diperolehnya di luar sekolah.

Terkait dengan penerapannya di kelas bahasa Inggris, penilaian harus mencakup tiga domain pembelajaran yang dilakukan melalui pengajaran keterampilan makro kebahasaan: mendengarkan, berbicara, membaca, dan menulis. Selain itu, kreativitas guru dalam menilai pencapaian kompetensi siswa sangat diperlukan karena beberapa kinerja otentik dalam pembelajaran bahasa asing hanya dapat diperoleh melalui penggunaan bahasa target dalam situasi nyata. Ini berarti bahwa interpretasi guru terhadap penilaian otentik dalam praktek ELT baru pada level konseptual dan diasumsikan berdasarkan pengetahuan mereka yang berasal dari sumber yang sama.

\section{SIMPULAN}

Persepsi guru bahasa Inggris terhadap perubahan kurikulum dari KTSP ke K-13 dalam pengajaran bahasa Inggris mengarah pada dua kecenderungan utama. Kecenderungan pertama berasal dari guru yang melihat perubahan kurikulum sebagai sesuatu yang positif, inovatif, dan kreatif dalam praktek pembelajaran bahasa Inggris untuk masa depan Indonesia. Perubahan ini juga memberikan dampak terhadap transformasi cara pandang guru dan siswa dari pandangan tradisional menuju dimensi pedagogik modern. Kecenderungan kedua memandang perubahan kurikulum sebagai perubahan yang bersifat formalitas dan konseptual, serta kemungkinan akan memiliki efek yang sama dengan perubahan kurikulum sebelumnya. Kedua kecenderungan persepsi guru tampaknya sejalan dengan pengetahuan dan sistem kepercayaan guru dalam memandang perubahan. Pengetahuan dan sistem kepercayaan yang dimiliki oleh guru dihubungkan dengan pengalaman mereka melaksanakan kurikulum sebelumnya.

Penafsiran guru terhadap perubahan kurikulum dari KTSP ke K-13 dalam praktik pembelajaran Bahasa Inggris terbagi menjadi dua bagian. Pertama, interpretasi benar dan komprehensif ketika dihadapkan dengan konsep-konsep umum dalam K-13 terkait pembelajaran bahasa Inggris.Kedua, interpretasi yang agak mengambang dan parsial ketika dihadapkan dengan materi yang prosedural terkait pembelajaran bahasa Inggris.Pemahaman parsial guru didasari oleh tingkat pengetahuan dan pemahaman prosedural guru yang diperoleh dari Bimtek atau sumber lain serta kenyamanan dan kemudahan yang ditawarkan dari elemen kurikulum yang berubah.Oleh karena itu, terlepas dari kapasitas individu menciptakan atmosfir pembelajaran yang lebih baik bagi siswa seperti yang diinginkan oleh K-13, persepsi dan interpretasi guru terhadap K-13 dalam kaitannya dengan praktik pembelajaran bahasa Inggris dipostulatkan sejalan dengan pengetahuan dan keyakinan, pola pikir dalam praktekpembelaj aran, tuntutan kebijakan pemerintah dalam tugas-tugas administrasi guru.

\section{DAFTAR PUSTAKA}

Basturkman, PL, Loewen, S., and Ellis, R. 2004. "Teachers' stated beliefs about 
incidental focus on form and their classroom practices', Applied linguistics, vol. 25, no. 2, pp. 243-72.

Bekalo, S, and Welford, G. 2000. Practical activity in Ethiopian secondary physical sciences: Implications for policy and practice of the match between the intended and the implemented curriculum. Research Papers in Education, 15 (2), pp. 185-212.

Connelly F. M., and Lantz, O. C. 1991. Definitions of curriculum: An introduction. In A. Lewy (Ed.), The international encyclopaedia of curriculum (pp. 15-18). New York: Pergamon Press.

Dubin, E, and Olshtain, E. 1986. Course design: Developing programs and materials forlanguage learning. Cambridge: Cambridge University Press.

Elmore, R., and Sykes, G. 1992. Curriculum policy. In Philip W. Jackson (Ed.), Handbook ofresearch on curriculum: $A$ project of the American Educational Research Association. New York: Macmillan.

Karavas-Doukas, E. 1995. Teacher identified factors affecting the implementation of acurriculum innovation in Greek public secondary schools. Language, Culture andCurriculum, 8(1), 53-68.

Kementerian Pendidikan dan Kebudayaan. 2013. Konsep pendekatan Scientific. (PowerPoint). Jakarta: Badan Pengembangan Sumber Daya Manusia Pendidikan dan Kebudayaan, dan Penjaminan Mutu Pendidikan Kementerian Pendidikan dan Kebudayaan.

Krahnke, K. 1987. Approaches to syllabus design for foreign language teaching. Englewood Cliff, NJ: Prentice-Hall.

Lundeberg, M.A., and Levin, B.B. 2003. "Prompting the development of preservice teachers" beliefs through cases, action research, problem-based learning, and technology", in J Raths and A McAninch (eds), Teacher Beliefs and Classroom Performance: The Impact of Teacher Education, Information Age Publishing, Greenwich, CT, pp. 23-42.

Markee, N. 1993.The diffusion of innovation in language tezching. Annual Review of Applied Linguistics: Issues in second language teaching and learning, 13, 229-243.

Miles, M.. B., and Huberman, A.M. 1984. Qualitative Data Analysis. Califotnia: Sage Publications, Inc.

Nunan, D. 1988.Syllabus design.Oxford: Oxford University Press.

O'Sullivan, M. C. 2002. Reform implementation and the realities within which teachers work: A Namibian case sftxdy.Compare, 32 (2), pp. 219-237.

Permendikbud Nomor 65 Tabun 2013 tentang Standar Proses Pendidikan Dasar dan Menengah.

Richardson, V. 2003."Constructivist pedagogy", Teachers College Record, vol. 105, no. 9, pp. 1623-40.

Robertson, A. S. 1971. Curriculum building. In L. C. Deighton (Ed.), The encyclopedia of education (pp. 564-575). New York: Macmillan.

Rodgers, T. S. 1989. Syllabus design, curriculum development and policy determination. In R. K. Johnson (Ed.), The second language curriculum (pp. 24-34). Cambridge: Cambridge University Press.

Senior, R.M. 2006. The Experience of Language Teaching. New York: Cambridge University Press.

Yalden,J. 1987'. Principles of course design for language teaching. Cambridge: Cambridge University Press. 